\title{
ANTIOXIDANT ACTIVITY OF ALKOXY DERIVATIVES OF (QUINOLINE-4-YLTHIO)CARBOXYLIC ACIDS
}

\author{
O. O. BRAZHKO', M. P. ZAVGORODNY', O. S. KRUGLYAK ${ }^{2}$, \\ L. O. OMELJANCHIK ${ }^{1}$ G. A. SHAPOVAL ${ }^{2}$ \\ ${ }^{1}$ Zaporizhzhya National University, Ukraine; \\ ${ }^{2}$ Institute of Bioorganic Chemistry and Petrochemistry, \\ National Academy of Sciences of Ukraine, Kyiv; \\ e-mail: hellen.brazhko@gmail.com
}

\begin{abstract}
A selection of potential bioactive molecules including alkoxy derivatives of (quinoline-4-ylthio)carboxylic acids using virtual screening has been carried out and their biological activity was determined. The studied substances proved to be low-toxic, biologically active compounds. It was established that 4-thio derivatives of quinoline exhibit pronounced antiradical, antioxidant effects and can act as preventive antioxidants, radio and cytoprotectors.
\end{abstract}

Key words: 4-thioquinolines, mercaptocarboxylic acids, PASS-prognosis, toxicity, antiradical and antioxidant activity.

$\mathrm{O}$ ne of the most important tasks of the medical and pharmaceutical research is the extension of range of modern medication via the development of new biologically active compounds. The development methods are based on the synthetic modifications of the structures of these molecules to reduce toxicity and enhance selectivity [1]. Thus, nitrogen-containing heterocyclic compounds, in particular quinoline derivatives, are a promising base for creating new effective medical substances. Nowadays various quinoline derivatives are used as synthons in organic synthesis and molecular design as well as effective bioactive compounds. There is a particular interest in mercaptoderivatives of six-membered nitrogen-containing heterocycles, among which many bioactive molecules affecting the processes of free radical oxidation (FRO) were found [2-4].

During FRO a series of products of interactions between free radicals (FR) and between FR and biological macromolecules was formed [5-9]. Thus, along with reactive oxygen species (ROS) other reactive radicals (such as peroxides, epoxides, aldehydes, ketones, alkohols, dialdehydes etc.) are formed. These radicals can interact with certain functional groups of proteins that may lead to their polymerizations and can damage amino acid residues, particularly SH-, SCH-groups of cysteine and methionine, $\mathrm{NH}$-group of lysine etc. All these processes cause the modifications of proteins (including enzymes), alterations in their activity, damage of bio antioxidants (such as vitamins, ubiquinone, steroid hormones etc.). Changes in phospholipid compositions can also be caused, when oxidation products form in the hydrophobic part, which induces ion transport and also alters protein conformations and lipids composition. This in turn leads to changes in structural and functional characteristics of membranes. The same processes can be observed in DNA structure of defective cells. Free radicals can react both directly with DNA nitrogenous bases, forming their modified derivatives (including 8-azaguanin) and indirectly through the secondary and end-products of lipid peroxidation (LPO), including malondialdehyde and its derivatives [10].

In most of pharmacological and clinical studies antioxidant effects of medications and physiologically active substances (PAS) are studied using the complex models of experimental pathology (acute cerebrovascular accident, myocardial infarction, emotionally painful stress, toxic liver damage, etc.). It should be noted that in many cases these methods do not allow to sufficiently evaluate the initial antioxidant and antiradical effects of the studied PAS, since these effects could be indirect, that is resultant of complex biochemical and physiological processes, which occur in vitro and do not reflect the initial molecular mechanism of the studied PAS action in biophagy [6]. 
It is highly necessary to apply methods of primary assessment of antioxidant and antiradical properties of PAS in experiments in vitro to explore AOA of potential medication, particularly in the early phases of biological screening. At the same time, it is reasonable to use several models of free-radical reactions initiation in experiments in vitro, which reflect various phases of complex chain reactions of FRO activation $[8,10]$.

To date systematic research has been conducted on investigation of bioactive molecules among thioderivatives of six-membered quinoline azaheterocycle, which are effective FR "scavengers" and are capable of inhibiting lipid peroxidation processes and show antiradical, antioxidant, antihypoxic, hepato-, cardio-, neuro- and radioprotective effects $[2-4,11$, 12].

The aim of this work is to select potential antioxidants, radio- and cytoprotector among alkoxy derivatives (quinoline-4-ylthio)carboxylic acids (using virtual screening), to study their acute toxicity, antioxidant activity in experiments in vitro and assess the prospects of these compounds as potential bioactive molecules.

\section{Materials and Methods}

PASS (Prediction of Activity Spectra for substances) software was used for the prediction of biological activity of the studied compounds. The probability of the biological activity was expressed as probability indicator $\mathrm{P}_{\mathrm{a}}$ (active) and indicator $\mathrm{P}_{\mathrm{i}}$ (inactive). Prediction was based on the analysis of structure of chemical compounds and on the analysis of structure-activity relationship (from known data) [13].

Wild type male mice with weight 20-24 g were used in experiments for assessment of acute toxicity parameters of the studied compounds. The substances were introduced intraperitonealy. Acute toxicity was determined by express-method [14].

Antioxidant activity of the synthesized compounds in vitro using free radicals initiation processes was assessed accordingly to $[15,16]$.

Methods used in our work for the assessment of the studied compounds AOA, in vitro $(n=5)$ differed in the mechanism of free radical initiation, in the substrates for oxidation and the marker products [15].

Assessment of inhibition of auto oxidation of adrenaline to adrenochrome. Nonenzymatic oxidation of adrenaline to adrenochrome in alkaline me- dium leads to accumulating of superoxide radicals. Rate of the reaction in biological systems depends on superoxide dismutase enzyme activity although this reaction in a chemical system in vitro may be used for quantitative assessment AOA of the studied compounds.

Assessment of AOA of the studied compounds by evaluation of NO-radical inhibition is based on sodium nitroprusside photoinduction which results in accumulating of $\mathrm{NO}^{-}$-radicals. Rate of ascorbate oxidation was measured at $\mathrm{d}=265 \mathrm{~nm}$.

Assessment of AOA of the studied compounds by evaluation of inhibition of proteins oxidative modifications, caused by Fenton's reagent is based on quantitative analysis of proteins oxidized amino acid residues which are formed during FRO initiating by Fenton's reagent in vitro using reaction with 2,4-dinitrophenylhydrazine (2,4-DNPH).

All of the mentioned above methods were reported in the work [15].

Assessment of AOA of the studied compounds by differential pulse voltammetry. The peak wave intensity of oxygen reduction on platinum cathode in the presence of the studied compounds characterizes their relative AOA which is associated with the interaction between studied compounds and active products of oxygen reduction [17]. The relative antiradical and antioxidant activities of the studied compounds were determined by analyzing the alterations in the wave peaks of reduction of hydroxyl radicals $(\mathrm{E}=-0.2 \mathrm{~V})$ and hydrogen peroxide $(\mathrm{E}=-1.1 \mathrm{~V})$ on copper cathode under the presence of the studied compounds [18].

Well known antioxidants (such as acetylcysteine (ACC), emoxypine, thiotriazoline) and base compounds such as (2-methylquinoline-4-ylthio)carboxylic acids were used as reference-substances [11] (Table 2).

The statistical data processing was performed using Student's $t$-test parametric criteria, MannWhitney nonparametric test and Microsoft Excel TM. The confidential interval of $95 \%(P<0.05)$ was used in the statistical analysis.

\section{Results and Discussions}

The most promising 9 substances ( $\mathrm{BO}-2-7$, $\mathrm{O}-1-3$ ), which have structures as shown in Fig. 1 considering PASS-predictions results and our own studies [2-4, 11, 12], were selected from 30 different chemical structures of 4-thioquinolines.

The probability of having antioxidant, membrane and radioprotective effects in these com- 
<smiles>[R]c1ccc2c(SC(C)C)cc([R])nc2c1</smiles>

$\mathrm{R}=\mathrm{Alk} ; \mathrm{R}^{\prime}=\mathrm{OAlk} ; \mathrm{R}^{2}=\mathrm{H}, \mathrm{CH} 3, \mathrm{CH}_{2} \mathrm{COOH}, \mathrm{NH}_{2}$; $n=0 ; 1$

Fig. 1. Structure of (quinoline-4-ylthio)carboxylic acids

pounds approaches $47 \%$. Thus, further studies of these compounds are considered to be promising. Structures of the derivatives of (quinoline-4-ylthio) carboxylic acids conform to Lipinski's rule of five which determine criteria for the prediction of any compound bioavailability, based on the observation of simple molecular characteristics (such as molecular weight, molar refractivity, lipophily, numbers of hydrogen bond donors and acceptors) [19].
It should be noted that prediction analysis indicated the presence of membrane protective effects in studied compounds and the absence of negative effects such as high toxicity, terato-, cancer-, mutagens and embryotoxicity.

Studying of quinoline derivatives acute toxicity showed that their $\mathrm{DL}_{50}$ are $930 \mathrm{mg} / \mathrm{kg}$ and higher. It allows to consider these compounds as low-toxic or nontoxic substances (IV and V toxicity classes respectively). Introducing alkoxygroups (methoxy- or ethoxy-) into benzene ring of quinolone structure considerably reduces toxicity that was proved in the works $[11,12]$. Compounds which have two alkoxygroups in their structure (marked as BO) are less toxic than compounds having only one alkoxygroup (marked as O).

Excessive levels of ROS, particularly superoxide radicals, produced by neurocytes at ischemia condition lead to the expression of proapoptotic proteins, anti-inflammatory cytokines and activation of inducible NO synthase. Superoxide radical is the main component of the reaction resulted in formation the most reactive cytotoxins such as hydroxyl

Ta b le 1. Prediction of biological activity of quinoline derivatives

\begin{tabular}{|c|c|c|c|c|c|}
\hline \multirow[b]{2}{*}{ Code } & \multicolumn{5}{|c|}{ Biological activity and $\mathrm{P}_{\mathrm{a}}, \mathrm{P}_{\mathrm{i}}$ values } \\
\hline & Oxygen scavenger & $\begin{array}{l}\text { Free radical } \\
\text { scavenger }\end{array}$ & Hepatoprotector & $\begin{array}{c}\text { Membrane } \\
\text { integrity agonist }\end{array}$ & Radioprotector \\
\hline BO-2 & & $\begin{array}{l}P_{a}-0.245 \\
P_{i}-0.048\end{array}$ & $\begin{array}{l}P_{a}-0.293 \\
P_{i}-0.062\end{array}$ & $\begin{array}{l}P_{a}-0.248 \\
P_{i}-0.238\end{array}$ & $\begin{array}{l}P_{a}-0.189 \\
P_{i}-0.156\end{array}$ \\
\hline BO-3 & & & $\begin{array}{l}P_{a}-0.334 \\
P_{i}-0.049\end{array}$ & & \\
\hline BO-4 & $\begin{array}{l}P_{a}-0.320 \\
P_{i}-0.157\end{array}$ & & $\begin{array}{l}P_{a}-0.349 \\
P_{i}-0.044\end{array}$ & $\begin{array}{l}P_{a}-0.394 \\
P_{i}-0.143\end{array}$ & \\
\hline BO-5 & $\begin{array}{l}P_{a}-0.337 \\
P_{i}-0.140\end{array}$ & & $\begin{array}{l}P_{a}-0.335 \\
P_{i}-0.048\end{array}$ & $\begin{array}{l}P_{a}-0.444 \\
P_{i}-0.122\end{array}$ & \\
\hline BO-6 & & & $\begin{array}{l}P_{a}-0.322 \\
P_{i}-0.053\end{array}$ & $\begin{array}{l}P_{a}-0.366 \\
P_{i}-0.156\end{array}$ & \\
\hline BO-7 & $\begin{array}{l}P_{a}-0.368 \\
P_{i}-0.116\end{array}$ & & $\begin{array}{l}P_{a}-0.367 \\
P_{i}-0.039\end{array}$ & $\begin{array}{l}P_{a}-0.553 \\
P_{i}-0.087\end{array}$ & $\begin{array}{l}P_{a}-0.367 \\
P_{i}-0.056\end{array}$ \\
\hline $\mathrm{O}-1$ & $\begin{array}{l}P_{a}-0.343 \\
P_{i}-0.136\end{array}$ & $\begin{array}{l}P_{a}-0.341 \\
P_{i}-0.024\end{array}$ & $\begin{array}{l}P_{a}-0.341 \\
P_{i}-0.046\end{array}$ & $\begin{array}{l}P_{a}-0.389 \\
P_{i}-0.145\end{array}$ & \\
\hline $\mathrm{O}-2$ & $\begin{array}{l}P_{a}-0.325 \\
P_{i}-0.152\end{array}$ & & $\begin{array}{l}P_{a}-0.328 \\
P_{i}-0.051\end{array}$ & $\begin{array}{l}P_{a}-0.319 \\
P_{i}-0.183\end{array}$ & \\
\hline $\mathrm{O}-3$ & & & $\begin{array}{l}P_{a}-0.368 \\
P_{i}-0.038\end{array}$ & & \\
\hline
\end{tabular}


radical and nitric oxide. So, the positive effect of quinoline thioderivatives on reducing of ROS level is of a particular interest. Thus, all studied compounds showed considerable anti-radical activity in experiments using the model of superoxide production (Table 2).

It was interesting to note that the compounds which contain two alkoxy groups in benzene ring of quinoline heterocycle and electron-acceptor substituents (carboxy-, carboxyalkyl- or amino groups) in the mercaptocarboxylic acid residue (compounds BO-3, BO-6 and BO-7) were the most effective. A similar characteristic was observed when using the model of NO-radical initiation.

Oxidative modification of neuron membrane proteins under ischemia leads to disorders in generation and transmission of nerve impulses as well as receptor desensitization, pore formation and resultant initiation of apoptosis and cognitive deficit. One of the key mechanisms of action of many known antioxidant-neuroprotectors is their ability to inhibit the processes of oxidative modification of proteins (OMP) and accumulating of carbonyl and carboxyl products such as aldehyde phenylhydrazone (APH) and carboxy phenylhydrazone (CPH). Therefore investigation of the compounds, which are capable of inhibiting processes of OMP is a promising direction [20].

The derivatives of (quinoline-4-ylthio)carboxylic acid showed AOA also when using the model of inhibition of oxidative modification of proteins. These compounds reduced rate of OMP (APH and $\mathrm{CPH})$ rather efficiently. The compounds $\mathrm{BO}-3$ and BO-7 demonstrated the highest activity in the mentioned above models of FRO initiation (Table 3).

Analysis of the total AOA of the most promising compounds BO-3, BO-5 and BO-6 using method of differential pulse voltammetry allowed to establish the following: the studied compounds affect the wave of oxygen reduction on platinum catho-

Ta b le 2. Antiradical activity of the studied compounds $\left(10^{-6} \mathrm{M}\right)$ in vitro assessed by evaluation of inhibition of superoxide $\left(\mathrm{O}_{2}^{-}\right)$and nitrogen monooxide $\left(\mathrm{NO} \mathrm{O}^{*}\right)(\mathrm{M} \pm m, n=5)$

\begin{tabular}{l|c|c|c|c}
\hline \multicolumn{1}{c}{ Compound code } & Absorbance, $\Delta$ & ARA, $\%$ & Absorbance, $\Delta$ & ARA, \% \\
\hline BO-2 & $0.074 \pm 0.001^{\text {bd }}$ & 63.0 & $0.249 \pm 0.061^{\mathrm{b}}$ & 18.7 \\
BO-3 & $0.056 \pm 0.001^{\text {bcd }}$ & 72.0 & $0.128 \pm 0.03^{\text {bce }}$ & 55.9 \\
BO-4 & $0.070 \pm 0.001^{\text {bd }}$ & 65.0 & $0.260 \pm 0.042^{\mathrm{b}}$ & 14.9 \\
BO-5 & $0.065 \pm 0.001^{\text {bd }}$ & 67.5 & $0.264 \pm 0.091$ & 13.7 \\
BO-6 & $0.058 \pm 0.001^{\text {bcd }}$ & 71.0 & $0.178 \pm 0.027^{\text {be }}$ & 41.8 \\
BO-7 & $0.063 \pm 0.001^{\text {bcd }}$ & 68.5 & $0.260 \pm 0.042^{\mathrm{b}}$ & 14.9 \\
ACC & - & - & $0.257 \pm 0.002^{\mathrm{b}}$ & 16.8 \\
Emoxypine & $0.163 \pm 0.006^{\mathrm{b}}$ & 18.5 & - & - \\
Thiotriazoline & $0.072 \pm 0.001^{\mathrm{bd}}$ & 35.8 & $0.186 \pm 0.028^{\mathrm{be}}$ & 39.2 \\
Intact & $0.026 \pm 0.0008$ & - & - & - \\
Control & $0.200 \pm 0.001^{\mathrm{a}}$ & - & $0.306 \pm 0.018$ & - \\
O-1 & $0.150 \pm 0.001^{\mathrm{bd}}$ & 25.0 & $0.218 \pm 0.045^{\mathrm{b}}$ & 28.8 \\
O-2 & $0.175 \pm 0.001^{\mathrm{bd}}$ & 63.0 & $0.249 \pm 0.061^{\mathrm{b}}$ & 18.7 \\
Intact & $0.020 \pm 0.001$ & - & - & - \\
Control & $0.220 \pm 0.001^{\mathrm{a}}$ & - & $0.306 \pm 0.018$ & - \\
O-3 & $0.140 \pm 0.00^{1 \mathrm{~b}}$ & 30.0 & $0.288 \pm 0.025^{\mathrm{b}}$ & 5.8 \\
Intact & $0.021 \pm 0.002$ & - & - & - \\
Control & $0.200 \pm 0.001^{\mathrm{a}}$ & - & $0.306 \pm 0.018$ & - \\
(2-Methylquinoline-4-ylthio)acetic acid & - & 42.0 & - & - \\
(2-Methylquinoline-4-ylthio)propionic acid & - & 33.0 & - & - \\
\hline P & -0.05 & - & - \\
\hline
\end{tabular}

${ }^{\text {a }} P<0.05$ in relation to intact; ${ }^{\mathrm{b}} P<0.05$ in relation to control; ${ }^{\mathrm{c}} P<0.05$ in relation to thiotriazoline; ${ }^{\mathrm{d}} P<0.05$ in relation to emoxypine; ${ }^{\text {e }} P<0.05$ in relation to ACC. 
Ta b le 3. Antioxidant activity of the studied compounds in vitro assessed by evaluation of inhibition of oxidative modification of proteins $(M \pm m, n=5)$

\begin{tabular}{l|c|c|c|c}
\hline \multicolumn{1}{c}{ Code } & APH, c.u./g & AOA, $\%$ & CPH, c.u./g & AOA, \% \\
\hline BO-2 & $0.64 \pm 0.11 \mathrm{~d}$ & 19.0 & $0.13 \pm 0.02^{\mathrm{b}}$ & 29.3 \\
BO-3 & $0.45 \pm 0.09^{\mathrm{bcd}}$ & 41.3 & $0.13 \pm 0.03^{\mathrm{bcd}}$ & 60.7 \\
BO-4 & $0.60 \pm 0.16^{\mathrm{b}}$ & 21.1 & $0.24 \pm 0.10^{\mathrm{b}}$ & 29.2 \\
BO-5 & $0.58 \pm 0.04^{\mathrm{d}}$ & 23.4 & $0.23 \pm 0.17^{\mathrm{b}}$ & 31.9 \\
BO-6 & $0.54 \pm 0.09^{\mathrm{b}}$ & 29.0 & $0.26 \pm 0.07^{\mathrm{b}}$ & 22.6 \\
BO-7 & $0.50 \pm 0.02^{\mathrm{bd}}$ & 34.5 & $0.19 \pm 0.03^{\mathrm{bd}}$ & 42.6 \\
Control & $0.76 \pm 0.10^{\mathrm{a}}$ & - & $0.34 \pm 0.02^{\mathrm{a}}$ & - \\
Intact & $0.22 \pm 0.01$ & - & $0.10 \pm 0.003$ & - \\
Emoxypine & $0.55 \pm 0.08^{\mathrm{b}}$ & 28.0 & $0.23 \pm 0.07^{\mathrm{b}}$ & 32.2 \\
Thiotriazoline & $0.48 \pm 0.03^{\mathrm{bd}}$ & 36.8 & $0.18 \pm 0.05^{\mathrm{bd}}$ & 46.4 \\
O-3 & $0.70 \pm 0.04^{\mathrm{b}}$ & 8.0 & $0.29 \pm 0.02^{\mathrm{b}}$ & 13.7 \\
Control & $0.76 \pm 0.10^{\mathrm{a}}$ & - & $0.34 \pm 0.02^{\mathrm{a}}$ & - \\
Intact & $0.22 \pm 0.01$ & - & $0.10 \pm 0.003$ & - \\
\hline
\end{tabular}

${ }^{\mathrm{a}} \mathrm{P}<0.05$ in relation to intact; ${ }^{\mathrm{b}} \mathrm{P}<0.05$ in relation to control; ${ }^{\mathrm{c}} \mathrm{P}<0.055$ in relation to thiotriazoline; ${ }^{\mathrm{d}} \mathrm{P}<0.05$ in relation to emoxypine.
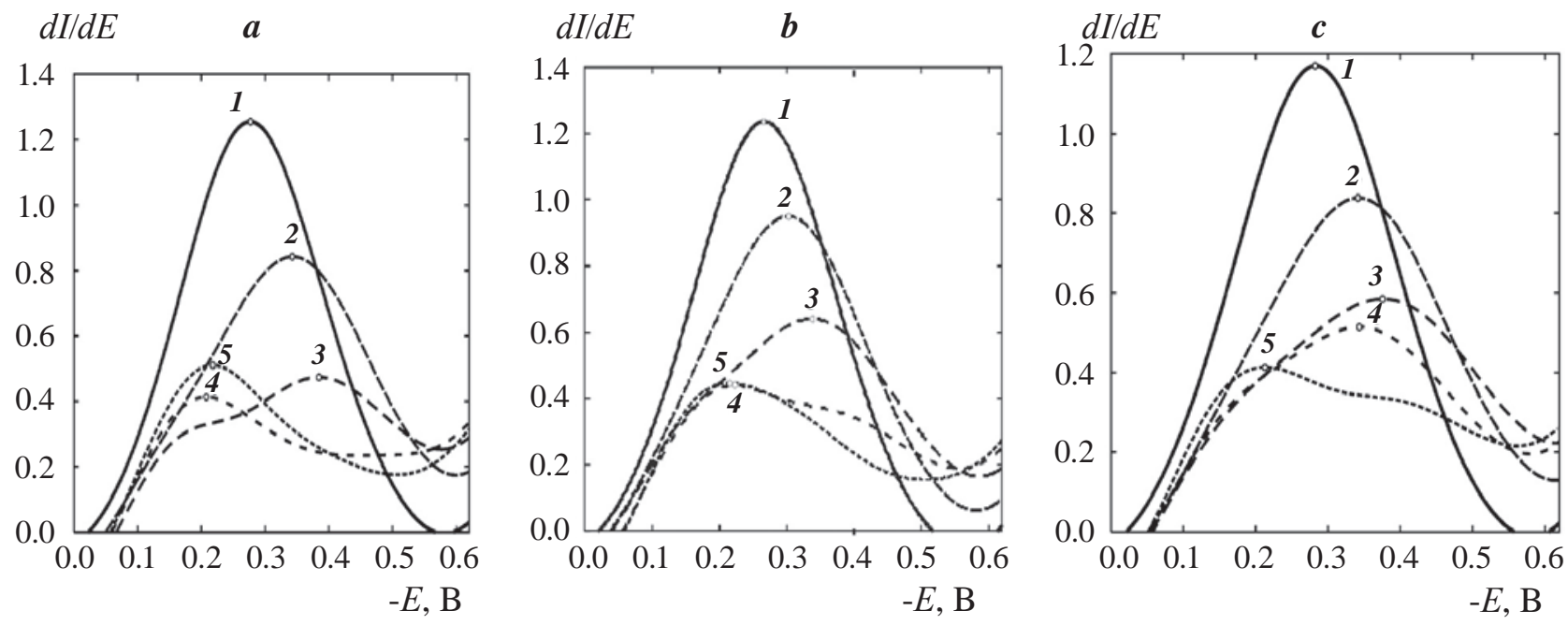

Fig. 2. Differential voltammograms of oxygen reduction on platinum cathode in the presence of $0.1 M$ NaClaq (1) and in the presence of the compounds BO-3 (a), BO-5 (b), BO-6 (c) at concentrations: 2 - $0.1 \mathrm{mM} ; 3$ $0.2 \mathrm{mM} ; 4-0.3 \mathrm{mM} ; 5-0.4 \mathrm{mM}$

de, reducing the height of the wave peak (Fig. 2). The intensities of these reductions are different. We determined the relative alteration of the height of oxygen wave to compare the obtained results. The relative alteration was defined as a quotient of the height of initial peak of oxygen wave divided by the height of oxygen wave peak in the presence of the studied compounds (their concentrations were the same).
The obtained data presented in Table 4 indicated that BO-3 showed the highest total AOA and BO-5 showed the lowest total AOA. Method of simultaneous generating of hydroxyl radicals and hydrogen peroxide during electrochemical reduction of oxygen on copper cathode (special pulse mode) allows a more extensive understanding of molecular mechanism of AOA [18]. 


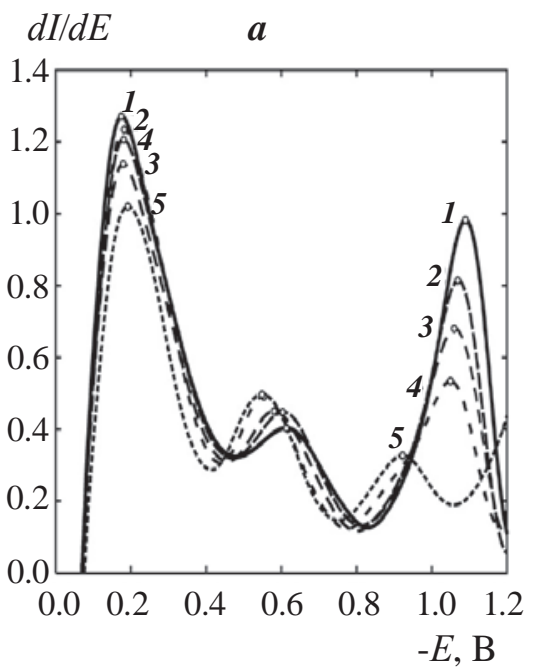

\section{$d I / d E$}

$\boldsymbol{b}$

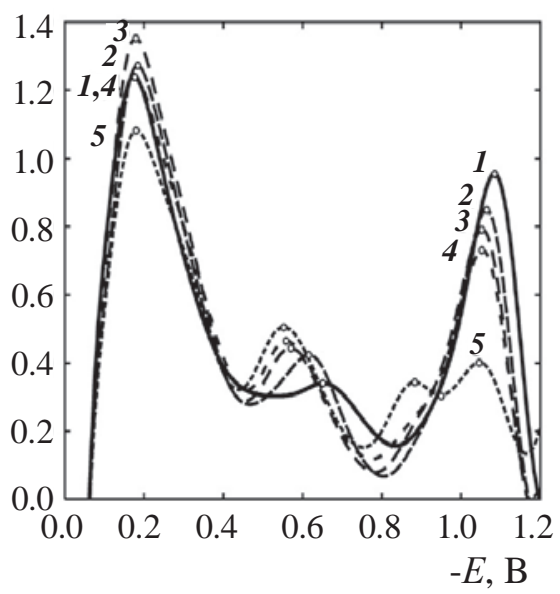

$d I / d E$

C

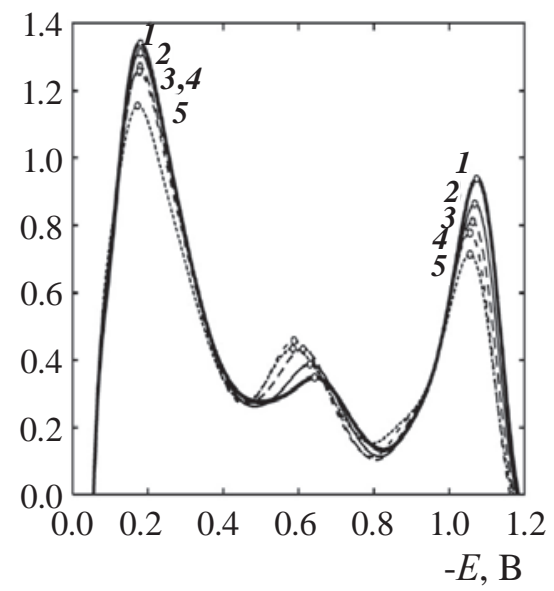

Fig. 3. Differential voltammograms of oxygen reduction on cooper cathode in the presence of $0.1 M$ NaClaq (1) and in the presence of the compounds BO-3 (a), BO-5 (b), BO-6 (c) at concentrations: $2-0.1 \mathrm{mM} ; 3-0.2 \mathrm{mM}$; $4-0.3 \mathrm{mM} ; 5-0.4 \mathrm{mM}$

Addition of the studied compounds into electrochemical cell allows observation of the results of their interactions both with hydroxyl radicals and with soluble oxygen itself. Quinoline derivatives BO-3 and BO-6 decreased wave peaks of hydroxyl radicals and hydrogen peroxide, whereas $\mathrm{BO}-5$ at low concentrations increased wave peaks of hydroxyl radicals causing pro-radical effect. Compound (BO-5) showed antiradical effects at concentrations of $0.3 \mathrm{mM}$ and higher, whereas antioxidative effect occurred at concentrations less than $0.2 \mathrm{mM}$ (Fig. 3).

The relative rate of antiradical and antioxidant activity of the studied compounds were determined in relation to initial height of wave peak of hydroxyl radicals and wave peak of hydrogen peroxide to the height of peaks in the presence of studied compounds. It was established that compound BO-3 showed the highest effect (Table 4). Furthermore, it should be noted that quinoline thioderivatives have effect on oxygen wave itself. The wave height is raised and potential of the peak is shifted to the anode side. It is evident that oxygen forms complexes with each compound and in these forms can be more easily reduced, which can have an input into the AOA of the studied compounds.

Thus, high antioxidant, membrane, cyto-, and radioprotector effects of alkoxy derivatives (2-methylquinoline-4-ylthio)carboxylic acids were revealed using virtual screening. It has been shown that the studied compounds are low or nontoxic. Introduction of two alkoxy groups to quinoline ring leads to lower toxicity. It was observed that alkoxy derivatives of (2-methylquinoline-4-ylthio)carboxylic acids revealed significant AOA, when using the models of initiating of FRO in vitro (such as generating of superoxide-anion and nitric oxide and also by inhibition of oxidative modification of proteins). Introduction of electron acceptor functional groups into structure of mercapto carboxylic acids enhanced their action. It was determined that compound BO-3 showed the highest effect on total wave of electrochemically generated ROS according to the results of pulse voltammetry. The obtained results have proved the appropriateness of study of quinoline

Ta ble 4. Antioxidant, antiradical and antioxidative activities of the studied compounds

\begin{tabular}{c|c|c|c}
\hline Code & Total AOA $(\mathrm{C}=0.2 \mathrm{mM})$ & $\begin{array}{c}\text { Antiradical activity } \\
(\mathrm{C}=0.4 \mathrm{mM})\end{array}$ & $\begin{array}{c}\text { Antioxidative activity } \\
(\mathrm{C}=0.4 \mathrm{mM})\end{array}$ \\
\hline BO-3 & 2.67 & 1.3 & 3.4 \\
BO-5 & 1.6 & 1.0 & 2.81 \\
BO-6 & 1.9 & 1.22 & 1.61 \\
\hline
\end{tabular}


4-thioderivatives as potential cyto- and radioprotectors in experiments in vivo.

\section{АНТИОКСИДАНТНА АКТИВНІСТЬ АЛКОКСИЗАМІЩЕНИХ (ХІНОЛІН-4- ІЛТІО)КАРБОНОВИХ КИСЛОТ}

\author{
О. О. Бражко1, М. П. Завгородній \\ О. С. Кругляк', Л. О. Омельянчик', \\ Г. С. Шаповал ${ }^{2}$
}

13апорізький національний університет, Україна; ${ }^{2}$ Інститут біоорганічної хімії та нафтохії НАН України, Київ; e-mail: hellen.brazhko@gmail.com

Проведено відбір задопомогою віртуального скринінгу потенційних біоактивних молекул серед алкоксипохідних (хінолін-4-ілтіо)карбонових кислот та визначено їхню біологічну активність. Досліджувані речовини виявили себе як малотоксичні біологічно активні сполуки. Встановлено, що 4-тіопохідні хіноліну мають виражений антирадикальний, антиокислювальний ефект і можуть відігравати роль превентивних антиоксидантів, радіо- та цитопротекторів.

К л ю ч о в і с л о в а: 4-тіопохідні хіноліну, меркаптокарбонові кислоти, PASS-прогноз, токсичність, антирадикальна, антиокислювальна та антиоксидантна активність.

\section{АНТИОКСИДАНТНАЯ АКТИВНОСТЬ АЛКОКСИЗАМЕЩЕННЫХ (ХИНОЛИН-4-ИЛТИО)КАРБОНОВЫХ КИСЛОТ}

\section{Е. А. Бражко ${ }^{1}$, М. П. Завгородний А. С. Кругляк², Л. А. Омельянчик', Г. С. Шаповал ${ }^{2}$}

\section{${ }^{13 а п о р о ж с к и и ̆ ~ н а ц и о н а л ь н ы и ̆ ~ у н и в е р с и т е т, ~ У к р а и н а ; ~}$ ${ }^{2}$ Институт биоорганической химии и нефтехимии НАН Украины, Киев; e-mail: hellen.brazhko@gmail.com}

Проведен отбор с помощью виртуального скрининга потенциальных биоактивных молекул среди алкоксипроизводных (хинолин4-илтио)карбоновых кислот и определена их биологическая активность. Исследуемые соединения проявили себя как малотоксичные биологически активные вещества. Установлено, что 4-тиопроизводные хинолина имеют выраженный антирадикальный, антиокислительный эффект и могут играть роль превентивных антиоксидантов, радио- и цитопротекторов.

К лю юе вы е слов а: 4-тиопроизводные хинолина, меркаптокарбоновые кислоты, PASSпрогноз, токсичность, антирадикальная, антиокислительная и антиоксидантная активность.

\section{References}

1. General toxicology / Ed. B. A. Kurlandsky, V. A. Filov. M.: Medicine, 2002; 608 p. (In Russian).

2. Ulischenko E. O., Brazhko O. A., Omelyanchik L. O. Virtual screening and synthesis of novel N-acyl derivates of S-(2-methylquinoline4-yl)-L-cysteine as a potential bioregulators directional. Med. Chem. 2012;14(3(52)):94-99. (In Ukrainian).

3. Labenska I. B., Shapoval G. S., Kruglyak O. S., Omelyanchik L. O., Brazhko O. A., Zavgorodniy M. P. Dependence of biological activity of $\mathrm{N}$-acyl derivates of 6-alkoxy-2-methyl-4merkaptohinoline on the nature of the substituents in the position heterocycle. Ukr. Biokhim. Zhurn. 2010;82(3):49-54. (In Ukrainian).

4. Gencheva V.I., Omelyanchik L. O., Brazhko O. A. Biological activity of S-substituted 2-methyl4-mercapto-8-methoxyquinoline. J. DonNU. 2010;(2):224-228. (In Ukrainian).

5. Baraboi V. A. Bioantioxidants. K.: Book Plus, 2006; 460 p. (In Russian).

6. Bioantioxidants and free radical pathology / Ed. O. N. Voskresenskyi. Poltava, 1987; 154 p. (In Russian).

7. Vladimirov Y. A., Archakov A. I. Lipid peroxidation in biological membranes. Moscow: Nauka, 2003; P. 230-272. (In Russian).

8. Gubsky Yu. I., Yurzhenko N. N., Shapoval G. S., Gromovaya V. F., Goryushko A. G., Averkov A. J. Study of antiradical and antioxidative activities of some membrane tropic synthetic and plant drugs. Ukr. Biokhim. Zhurn. 1998;70(3)128-134. (In Russian).

9. Racay P., Qteishat A. W., El Kambergy H. Fe ${ }^{2+}$ induced inhibition of gerbil forebrain microsomal $\mathrm{Ca}^{2+}$-ATPase: Effect of stobadine, glutathione and combination of both antioxidants. Biochem. Biophys. Acta. Biomembranes. 1998;1370(1):119126.

10. Belenichev I., Pavlov S., Sokolik E. Effect of spin trapping compound $\mathrm{PBN}$ and thiotriazoline on the outcome from experimental middle cerebral 
artery occlusion. Mol. Pharmacol. 2010;1(3):9095.

11. Brazhko O. A., Omelyanchik L. O., Zavgorodniy M. P., Martynovsky O. O. Chemistry and biological activity of 2(4)-thioquinolines and 9-thioacridines. Monograph. Zaporizhzhya: ZNU, 2013; 236 p. (In Ukrainian).

12. Cornet M. M., Brazhko O. O., Kruglyak O. S., Shapoval G. S., Zavgorodniy M. P. Toxicity and antioxidant activity of 4-thioderivatives potential radioprotective properties. Pharmacol. Med. Toxicol. 2012;22(3):50-56. (In Ukrainian).

13. Filimonov D. Chemical similarity assessment through multilevel neighborhoods of atoms: fefinition and comparison with the other fescriptors. J. Chemical Inf. Comput. Sci. 1999;39(4):666-670.

14. Prozorovskiy V. B. Tabular rapid method of determining the mean effective impact on biological objects. Tox. Gazette. 1998;(1):28-32. (In Russian).

15. Methods of evaluation of the antioxidant activity of substances at the initiation of freeradical processes in studies in vitro: method. recommendations. K.: SPC Ministry of Ukraine, 2002; 26 p. (In Russian).
16. Pat. 40767 UA, ICP G 01 N21/00. A Technique for Determination of the Antioxidant Activity of Biologically Active Compounds (BAC). Shapoval H. S., Gromova V. P. Publ. 27.04.2009, Bul. N 8. (In Ukrainian).

17. Korotkova E. I., Avramchik O. A., Angelov T. M., Karbainov Y. A. Investigation of antioxidant activity and lipophilicity parameters of some preservatives. Electrochim. Acta. 2005;51(2):324332.

18. Shapoval G. S., Kruglyak O. S. Electrochemical modeling and definition of antioxidant activity. Zhurn. Obshchey Khimii. 2011;81(Iss. 7):10921099. (In Russian).

19. Lipinski C. A., Lombardo F., Dominy B. W. Experimental and computational approaches to estimate solubility and permeability in drug discovery and development settings. Adv. Drug Del. Rev. 1997;23:3-25.

20. Belenichev I. F., Bukhtiyarova N. V. Current approaches to the treatment of acute stroke. Neuroprotection strategies. Int. J. Neurological. 2010;32(2):137-147. (In Russian).

Received 10.09.2014 